\title{
Idiopathic pulmonary fibrosis in infants: good prognosis with conservative management
}

\author{
Doug Hacking, Rosalind Smyth, Nigel Shaw, George Kokia, Helen Carty, David Heaf
}

\begin{abstract}
Background-Pulmonary interstitial fibrosis in children is a disease of unknown aetiology, usually associated with a poor prognosis.

Methods-In this case series we describe 11 children presenting over a 10 year period, managed conservatively and associated with a good prognosis.

Results-In six, symptoms were present from birth and 10 had symptoms at or before 3 months. Diagnosis was made using chest computed tomography and percutaneous lung biopsy. All patients were treated with oral prednisolone. In five no steroid response was noted. One patient responded to hydroxychloroquine. Home oxygen was required in five patients. At follow up all patients are alive at a median age of 6 years (range 1 to 12 years). The two recently diagnosed children have significant symptoms, seven have dyspnoea on exercise, and two are symptom free.
\end{abstract}

Conclusion-The good prognosis seen in these patients is different to previous case reports, indicating a greater than $50 \%$ mortality.

(Arch Dis Child 2000;83:152-157)

Chitdal Unit, Royal

Flemington Road,

Melbourne, Australia

D Hacking

Respiratory Unit, Royal Liverpool Children's NHS Trust, Alder Hey Children's

Hospital, Eaton Road, Liverpool, UK

R Smyth

N Shaw

D Heaf

Pathology

Department, Royal

Liverpool Children's

NHS Trust

G Kokia

Department of

Radiology, Royal

Liverpool Children's

NHS Trust

H Carty

Correspondence to:

Dr D Hacking, Paediatric Specialist Registrar,

Department of Paediatrics,

Wexham Park Hospital,

Wexham, Slough, Berks

SL2 4HL, UK

email:

hackandmack@1wcdial.net

Accepted 22 March 2000
Keywords: idiopathic; pulmonary fibrosis

Pulmonary interstitial fibrosis in children is a heterogeneous group of progressive lung disorders characterised by a pattern of inflammation and subsequent interstitial fibrosis that predominantly affects the alveolar walls and perialveolar structures. ${ }^{1}$ In a minority of cases interstitial lung fibrosis develops as a result of a known insult to the lung such as infections, drugs, environmental inhalants, and autoimmune diseases. Most cases of pulmonary fibrosis have no associated aetiology and are classified by histological features which include usual interstitial pneumonitis (UIP), desquamative interstitial pneumonitis (DIP), lymphocytic interstitial pneumonitis (LIP), and bronchiolitis obliterans with organising pneumonia (BOOP). Idiopathic pulmonary fibrosis in children is rare and poorly understood. The prognosis in infancy is thought to be poor ${ }^{2-4}$; a recent case series ${ }^{2}$ recorded nine deaths out of ten patients. The authors suggested that a delay in diagnosis might have contributed to the poor prognosis. We report our experience over the past 12 years treating 11 infants with the diagnosis of idiopathic pulmonary fibrosis, all of whom have survived to a median age of 6 years (range 1 to 12 years).

\section{Materials and methods}

PATIENTS

Eleven patients (eight boys and three girls) presented to the Regional Respiratory Unit of the Royal Liverpool Children's Hospital at Alder Hey between 1986 and 1997. Median age at presentation was 5 months (range birth to 16 months). The diagnosis was made by typical clinical findings (such as dyspnoea and dry cough) in association with the radiological finding of diffuse interstitial infiltrate. The diagnosis was confirmed by histology on samples obtained by percutaneous lung biopsy ${ }^{5}$ in all but one case.

The patient hospital and general practice medical records were scrutinised for the time and nature of the first respiratory symptoms, the date of this first medical consultation, and the presenting complaint. Details of the pregnancy, perinatal history, family history, the age at which the child was referred to the Regional Respiratory Unit, and age of diagnosis were also noted.

INVESTIGATIONS

All patients underwent physical examination including assessment of growth and development, full blood count, blood electrolytes, liver function tests, and coagulation screen. Other investigations included immunoglobulins, viral serological, sweat test, autoantibodies, $\alpha_{1}$ antitrypsin, lymphocyte CD4 to CD8 ratios, skin allergy testing, upper gastrointestinal contrast studies, radioisotope milk scans, and echocardiograms. Assessment of hypoxia included either random pulse oximetry oxygen saturation or overnight oxygen saturation studies. Patients old enough to comply had their respiratory function (peak flow (PEF), forced expiratory volume in one second $\left(\mathrm{FEV}_{1}\right)$, and forced vital capacity (FVC)) measured at least annually. Radiological investigations on all patients included standard anterior posterior chest radiographs; all images since 1995 have been taken with computer digital enhancement, and computerised tomography was performed under general anaesthesia. Bronchoscopy and bronchoalveolar lavage was carried out in one child using a well recognised protocol. ${ }^{6}$

PERCUTANEOUS LUNG BIOPSY

Histological samples of the lung were obtained by fluoroscopically guided percutaneous needle biopsy using the standard described technique. ${ }^{5}$ The procedure was performed while the patient was ventilated under general anaesthesia. The biopsy site selected was the lung area of maximum infiltration that was furthest from major vessels and any cystic 
Table 1 Patient details

\begin{tabular}{|c|c|c|c|c|c|c|}
\hline & $\begin{array}{l}\text { Year of } \\
\text { presentation }\end{array}$ & $\begin{array}{l}\text { Birth weight } \\
\text { and gestation }\end{array}$ & $\begin{array}{l}\text { Sex and } \\
\text { current age }\end{array}$ & $\begin{array}{l}\text { Onset of } \\
\text { symptoms }\end{array}$ & $\begin{array}{l}\text { Age at } \\
\text { presentation }\end{array}$ & Age at biopsy \\
\hline 1 & 1987 & $\begin{array}{l}3.22 \mathrm{~kg} \\
\text { Term } \\
\text { 50th centile }\end{array}$ & $\begin{array}{l}\text { Female } \\
12 \text { years }\end{array}$ & 10 weeks & 7 months & 3.5 years \\
\hline 2 & 1987 & $\begin{array}{l}3.8 \mathrm{~kg} \\
\text { Term } \\
\text { 90th centile }\end{array}$ & $\begin{array}{l}\text { Male } \\
11 \text { years }\end{array}$ & Birth & 3 months & 2.5 years \\
\hline 3 & 1988 & $\begin{array}{l}3.2 \mathrm{~kg} \\
\text { Term } \\
\text { 10th centile }\end{array}$ & $\begin{array}{l}\text { Male } \\
11 \text { years }\end{array}$ & Birth & 5 weeks & 7 weeks \\
\hline 4 & 1989 & $\begin{array}{l}1.8 \mathrm{~kg} \\
34 \text { weeks } \\
50 \text { th centile }\end{array}$ & $\begin{array}{l}\text { Male } \\
10 \text { years }\end{array}$ & 4 weeks & 9 weeks & 10 weeks \\
\hline 5 & 1990 & $\begin{array}{l}2.2 \mathrm{~kg} \\
\text { Term } \\
\text { 10th centile }\end{array}$ & $\begin{array}{l}\text { Male } \\
9 \text { years }\end{array}$ & Birth & 5 months & 6 months \\
\hline 6 & 1992 & $\begin{array}{l}1.68 \mathrm{~kg} \\
34 \text { weeks } \\
50 \text { th centile }\end{array}$ & $\begin{array}{l}\text { Male } \\
7 \text { years }\end{array}$ & 3 months & 9 months & 9 months \\
\hline 7 & 1993 & $\begin{array}{l}1.24 \mathrm{~kg} \\
28 \text { weeks } \\
50 \text { th centile }\end{array}$ & $\begin{array}{l}\text { Male } \\
6 \text { years }\end{array}$ & Birth & Birth & 9 months \\
\hline 8 & 1994 & $\begin{array}{l}1.42 \mathrm{~kg} \\
33 \text { weeks } \\
3 \text { rd centile }\end{array}$ & $\begin{array}{l}\text { Male } \\
6 \text { years }\end{array}$ & 2 months & 16 months & 4 years \\
\hline 9 & 1995 & $\begin{array}{l}3.31 \mathrm{~kg} \\
\text { Term } \\
\text { 50th centile }\end{array}$ & $\begin{array}{l}\text { Male } \\
4 \text { years }\end{array}$ & Birth & 5 months & No histology \\
\hline 10 & 1995 & $\begin{array}{l}3.5 \mathrm{~kg} \\
\text { Term } \\
\text { 50th centile }\end{array}$ & $\begin{array}{l}\text { Female } \\
4 \text { years }\end{array}$ & 5 months & 6 months & 6 months \\
\hline 11 & 1997 & $\begin{array}{l}3.31 \mathrm{~kg} \\
\text { Term } \\
\text { 50th centile }\end{array}$ & $\begin{array}{l}\text { Female } \\
2 \text { years }\end{array}$ & Birth & 9 months & 10 months \\
\hline
\end{tabular}

areas identified on computed tomography (CT) scanning. Between one and two samples were taken on each occasion. No major complications occurred after the procedure. All patients remained well. The biopsy had to be repeated on one patient because of insufficient lung sample. One biopsy sample (patient 9) on further histological review was felt to unhelpful as it contained insufficient lung tissue.

HISTOLOGICAL ANALYSIS

All tissue samples were processed routinely for standard histological investigation (formalin fixed, paraffin embedded) and stained by the routine battery of staining methods including haematoxylin and eoxin, PAS, van Giesson, Masson Trichrome, and Prussian stain (for iron). In six cases touch imprints were made from the fresh tissue cores and stained by Giemsa and haematoxylin and eoxin method. Electron microscopic investigation was not performed in any of the cases. Immunohistochemistry (monoclonal antibody S100) was applied in only two cases (patients 2 and 5) in order to differentiate the mononuclear cells from the Langerhans cells in the chronic inflammatory infiltrate.

\section{Results}

PATIENT CHARACTERISTICS

Table 1 gives patient details and table 2 treatment response. The median age of first respiratory symptoms was at birth (range: birth to 5 months). Six were symptomatic at birth with 10 of the 11 presenting at or before 3 months of age. The most common presenting sign was tachypnoea associated with rib indrawing, occurring in nine cases. Four had significant cough while only one patient had symptoms of wheeze at presentation. The median time between first onset of symptoms and referral to our department was 18 weeks (range: birth to 14 months). The median age of diagnosis was 9 months (range: 7 weeks to 4 years). The median time taken for the diagnosis to be confirmed by biopsy (in 10 of the 11 patients) after referral was four weeks (range: 1 week to 3 years). Patient 9 had the diagnosis of fibrosing alveolitis made on clinical and radiological grounds as the lung biopsy contained insufficient lung tissue. At presentation at 9 weeks of age, patient 4 had increased interstitial shadowing of both lungs on a chest radiograph. A CT scan performed on the same day was suggestive of pulmonary fibrosis which was confirmed by biopsy one week later. A significant delay between the referral and final diagnosis was seen in three patients $(1,2$, and

Table 2 Patient treatment and response

\begin{tabular}{|c|c|c|c|c|c|}
\hline Patient & $\begin{array}{l}\text { Sex and } \\
\text { current age }\end{array}$ & Weight at presentation & $\begin{array}{l}\text { Current weight } \\
\text { and height }\end{array}$ & Treatment & Current symptoms \\
\hline 1 & $\begin{array}{l}\text { Female } \\
11 \text { years }\end{array}$ & $\begin{array}{l}6.56 \mathrm{~kg} \\
\text { Below } 10 \text { th centile }\end{array}$ & $\begin{array}{l}\text { Weight } 3 \text { rd centile } \\
\text { Height } 25 \text { th centile }\end{array}$ & $\begin{array}{l}\text { Prednisolone continued for } \\
6 \text { months }\end{array}$ & Exercise limitation \\
\hline 2 & $\begin{array}{l}\text { Male } \\
10 \text { years }\end{array}$ & $\begin{array}{l}5.58 \mathrm{~kg} \\
\text { Below 50th centile }\end{array}$ & $\begin{array}{l}\text { Weight } 50 \text { th centile } \\
\text { Height } 50 \text { th centile }\end{array}$ & $\begin{array}{l}\text { Prednisolone continued for } \\
1 \text { year and } 3 \text { months }\end{array}$ & Exercise limitation \\
\hline 3 & $\begin{array}{l}\text { Male } \\
10 \text { years }\end{array}$ & $\begin{array}{l}3.57 \mathrm{~kg} \\
\text { Below 3rd centile }\end{array}$ & $\begin{array}{l}\text { Weight } 3 \text { rd centile } \\
\text { Height } 3 \text { rd centile }\end{array}$ & $\begin{array}{l}\text { Prednisolone continued for } \\
2 \text { years and } 9 \text { months }\end{array}$ & Exercise limitation \\
\hline 4 & $\begin{array}{l}\text { Male } \\
9 \text { years }\end{array}$ & $\begin{array}{l}4.2 \mathrm{~kg} \\
50 \text { th centile }\end{array}$ & $\begin{array}{l}\text { Weight } 50 \text { th centile } \\
\text { Height } 50 \text { th centile }\end{array}$ & Prednisolone trial for 3 months only & Well \\
\hline 5 & $\begin{array}{l}\text { Male } \\
8 \text { years }\end{array}$ & $\begin{array}{l}5.8 \mathrm{~kg} \\
\text { 3rd centile }\end{array}$ & $\begin{array}{l}\text { Weight } 90 \text { th centile } \\
\text { Height } 90 \text { th centile }\end{array}$ & $\begin{array}{l}\text { Prednisolone continued for } \\
6 \text { years and } 3 \text { months, home oxygen }\end{array}$ & $\begin{array}{l}\text { Exercise limitation, } \\
\text { nocturnal oxygen }\end{array}$ \\
\hline 6 & $\begin{array}{l}\text { Male } \\
6 \text { years }\end{array}$ & $\begin{array}{l}6.5 \mathrm{~kg} \\
\text { Below 3rd centile }\end{array}$ & $\begin{array}{l}\text { Weight } 50 \text { th centile } \\
\text { Height } 50 \text { th centile }\end{array}$ & $\begin{array}{l}\text { Prednisolone continued for } \\
3 \text { years and } 3 \text { months }\end{array}$ & Well \\
\hline 7 & $\begin{array}{l}\text { Male } \\
5 \text { years }\end{array}$ & $\begin{array}{l}1.24 \mathrm{~kg} \\
50 \text { th centile }\end{array}$ & $\begin{array}{l}\text { Weight } 50 \text { th centile } \\
\text { Height } 50 \text { th centile }\end{array}$ & $\begin{array}{l}\text { Prednisolone trial for } 3 \text { months only, } \\
\text { home oxygen }\end{array}$ & Exercise limitation \\
\hline 8 & $\begin{array}{l}\text { Male } \\
5 \text { years }\end{array}$ & $\begin{array}{l}10.18 \mathrm{~kg} \\
\text { Below 50th centile }\end{array}$ & $\begin{array}{l}\text { Weight } 50 \text { th centile } \\
\text { Height } 50 \text { th centile }\end{array}$ & Prednisolone trial for 3 months only & Exercise limitation \\
\hline 9 & $\begin{array}{l}\text { Male } \\
3 \text { years }\end{array}$ & $\begin{array}{l}4.25 \mathrm{~kg} \\
\text { Below 3rd centile }\end{array}$ & $\begin{array}{l}\text { Weight } 3 \text { rd centile } \\
\text { Height } 10 \text { th centile }\end{array}$ & $\begin{array}{l}\text { Prednisolone trial for } 3 \text { months only, } \\
\text { home oxygen }\end{array}$ & Exercise limitation \\
\hline 10 & $\begin{array}{l}\text { Female } \\
3 \text { years }\end{array}$ & $\begin{array}{l}5.7 \mathrm{~kg} \\
\text { Below 3rd centile }\end{array}$ & $\begin{array}{l}\text { Weight } 3 \text { rd centile } \\
\text { Height } 10 \text { th centile }\end{array}$ & $\begin{array}{l}\text { Prednisolone continued for } \\
4 \text { months, home oxygen }\end{array}$ & Oxygen dependent \\
\hline 11 & $\begin{array}{l}\text { Female } \\
18 \text { months }\end{array}$ & $\begin{array}{l}5.56 \mathrm{~kg} \\
\text { Below 3rd centile }\end{array}$ & $\begin{array}{l}\text { Weight } 3 \text { rd centile } \\
\text { Head circumference } \\
\text { 10th centile }\end{array}$ & $\begin{array}{l}\text { Prednisolone for } 3 \text { months only, } \\
\text { home oxygen, chloroquine }\end{array}$ & Oxygen dependent \\
\hline
\end{tabular}


Table 3 Pulmonary function

\begin{tabular}{llllllll}
\hline Patient & 1 & 2 & 3 & 4 & 5 & 6 & Mean age \\
\hline Age (y) 1st RFT & 5 & 5 & 5 & 4 & 5 & 4 & $\begin{array}{l}4 \text { years and } 7 \\
\text { months } \\
7 \text { years }\end{array}$ \\
Age (y) last RFT & 8 & 7 & 8 & 7 & 7 & 6 & Mean RFT \\
& & & & & & & $65 \%$ \\
1st FVC & $74 \%$ & $55 \%$ & $50 \%$ & $88 \%$ & $47 \%$ & $75 \%$ & $70 \%$ \\
Last FVC & $66 \%$ & $59 \%$ & $57 \%$ & $80 \%$ & $59 \%$ & $99 \%$ & $79 \%$ \\
1 st FEV & $79 \%$ & $37 \%$ & $37 \%$ & $66 \%$ & $49 \%$ & $85 \%$ & $59 \%$ \\
Last FEV $_{1}$ & $63 \%$ & $34 \%$ & $30 \%$ & $76 \%$ & $46 \%$ & $82 \%$ & $55 \%$ \\
1st peak flow & $97 \%$ & $43 \%$ & $55 \%$ & $58 \%$ & $65 \%$ & $101 \%$ & $70 \%$ \\
Last peak flow $^{6}$ & $66 \%$ & $34 \%$ & $36 \%$ & $62 \%$ & $51 \%$ & $85 \%$ & $56 \%$ \\
\hline
\end{tabular}

Values in per cent predicted for height. ${ }^{8}$

RFT, respiratory function test.

8). This was because at presentation each had mild symptoms of bronchial reactivity and no evidence of hypoxia. Prior to referral for investigation, five of the 11 patients were thought to have recurrent lower respiratory tract infections. Patient 2 was thought to have tracheal stenosis. Patient 5 had right heart failure secondary to pulmonary hypertension and patient 7 was thought to have Wilson-Mikity syndrome. At the time of referral, seven of the 11 patients were failing to thrive, defined as a weight below the 10th centile.

PREGNANCY, PERINATAL, AND FAMILY HISTORY Seven of the infants were born at term after a normal pregnancy. Five term infants experienced symptoms from birth, of whom two required oxygen in the first few days of life. Four patients were born preterm; three required oxygen in the first week of life. Patient 11 was one of twins. On antenatal scan at 20 weeks of gestation she was noted to have intrauterine growth retardation. The other twin was born at a normal weight and has been well throughout. There was no familial history of fibrosing alveolitis or lung fibrosis in any of the patients.

\section{DIAGNOSIS AND INVESTIGATION}

All patients in the study showed evidence of diffuse bilateral interstitial shadowing on chest radiographs. On CT scan in nine patients the interstitial fibrosis was widely disseminated throughout both lungs. Patient 1 had fibrosis that on first CT scan was located only in the right middle lobe, while patient 4 had bilateral fibrosis localised to the middle and lower regions of the lung. In patient 8 , these changes evolved over a two year period. Evidence of bullae was noted on CT scan in three cases. Investigations were performed to exclude cystic fibrosis, viral respiratory infections, autoimmune disease, gastro-oesphagael reflux and aspiration, and immunodeficiency. Echocardiography where requested was normal in all cases apart from patients 5 and 10 . Patient 5 presented with pulmonary hypertension and mild right ventricular heart failure that had resolved when subsequently investigated. $\mathrm{Pa}-$ tient 10 was found to have a small and clinically insignificant foramen ovale. The bronchoalveolar lavage performed on patient 8 showed a cell count which was consistent with the histological diagnosis of fibrosing alveolitis (total cell count was raised and there was an increase in the percentage number of neutrophils ${ }^{2}$ ).

Respiratory function tests were performed in all children old enough to comply (see table 3 ). Restrictive pulmonary function was seen in all patients. There was no improvement in percent predicted lung function in the three year period between first and latest testing.

\section{HISTOLOGY}

All patients had a percutaneous lung biopsy performed. Patient 9 was excluded from the histological analysis as his biopsy sample did not contain sufficient lung tissue. All histological sections were reviewed by one pathologist (GK) and assessed for microscopic diagnostic features of idiopathic pulmonary fibrosis. These included:

- Lesions within alveolar septa such as oedema, fibrosis, elastic fibres

- The cellular contents of the alveolar septa: type 2 pneumocytes, lymphocytes, monocytes, fibroblasts, and polymorphonuclear cells

- The character of cellular content (lymphocytes, macrophages, polymorphonuclear cells) in alveolar lumina.

Table 4 summarises these findings.

Among a variety of lesions the most constant and striking histopathological changes were interstitial fibrosis, hyperplasia of type 2 pneumocytes, and interstitial inflammatory infiltrate. The intensity of the interstitial fibrosis was considerable in only two samples (patients 2 and 11), moderate in five, and mild in three. Hyperplasia of type 2 pneumocytes was considerable in one (patient 11), moderate in one, mild in six, and of only borderline intensity in two biopsy samples (patients 4 and 5). Chronic mononuclear interstitial inflammatory infiltrate consisting of lymphocytes and macrophages, was evident in

Table 4 Summary of histopathological findings of lung biopsies

\begin{tabular}{|c|c|c|c|c|c|c|c|c|c|c|}
\hline \multirow[b]{2}{*}{$\begin{array}{l}\text { Patient } \\
\text { no. }\end{array}$} & \multicolumn{8}{|c|}{ Alveolar septa } & \multicolumn{2}{|l|}{ Alveolar lumen } \\
\hline & Oedema & Fibrosis & $\begin{array}{l}\text { Elastic } \\
\text { fibres }\end{array}$ & Pneumocytes & Lymphocytes & Macrophages & Granulocytes & Fibroblasts & Lymphocytes & Macrocytes \\
\hline 1 & - & + & + & ++ & ++ & + & - & + & - & + \\
\hline 2 & + & +++ & ++ & + & + & + & + & ++ & + & + \\
\hline 3 & + & ++ & + & + & + & - & + & + & - & + \\
\hline 4 & + & + & + & - & + & + & - & ++ & - & - \\
\hline 5 & - & $+/++$ & + & - & + & - & - & + & - & + \\
\hline 6 & - & ++ & + & + & - & + & - & ++ & - & - \\
\hline 7 & - & ++ & + & + & - & + & - & ++ & - & - \\
\hline 8 & - & ++ & + & + & ++ & + & + & + & - & ++ \\
\hline 10 & - & + & + & + & + & + & - & + & - & + \\
\hline 11 & $+/-$ & +++ & ++ & +++ & - & ++ & - & +++ & + & ++ \\
\hline
\end{tabular}

Patient 9 excluded from the histological analysis. 
all biopsy samples and showed mild to moderate range of intensity. The density of lymphocytes was moderate in two, mild in five, and virtually absent in three samples (patients 6,7 , and 11). In one of them, instead of lymphocytes numerous plasma cells were detected (patient 11). Macrophages were moderately numerous in one sample (patient 11) and mild in seven. In two samples no macrophages were seen (patients 3 and 5). Neutrophil granulocytes were only present in small numbers and detected in three biopsy samples (patients 2, 3, and 8). The amount of elastic fibres in the interstitium and alveolar septae was assessed as moderate in two (patients 2 and 11) and mild in eight tissue samples. In addition, the number of fibroblasts was considerably raised in only one (patient 11), moderately in four, and slightly in five lung samples. The intraalveolar cell population consisted predominantly of macrophages. They were identified in small numbers in most of the samples. The macrophage number was high in one sample (patient 11), giving the appearance of a desquamative interstitial pneumonia. In addition the cytoplasm was loaded by iron (focal secondary haemosiderosis). Lymphocytes were rarely seen and detected only in small numbers in two samples (patients 2 and 11). Neutrophilic granulocytes were absent from alveolar spaces in all biopsy samples.

\section{TREATMENT}

All patients received an initial course of prednisolone $2 \mathrm{mg} / \mathrm{kg}$ for three months. A steroid response was noted in six patients. If there was no clinical response, then the steroids were withdrawn. Where a steroid response was seen, prednisolone was continued at 1-1.5 $\mathrm{mg} / \mathrm{kg}$ daily for one month before changing to alternate day treatment. The average length of a continued course of steroids was two years and five months (median one year and three months; range four months to six years and three months). In two infants side effects were noted. One infant had abdominal pain after which the steroids were withdrawn. Patient 5 had some Cushingoid features noted at 2 years of age after which his steroid dose was reduced. Patient 11 has continued to deteriorate despite oral prednisolone. Her steroids were stopped and treatment was changed to hydroxychloroquine with a good response. Six patients had reversible bronchial reactivity and responded to inhaled steroids and bronchodilators.

A dietitian assessed nutrition in every patient. Seven were failing to thrive and received high energy diet supplementation. Weight gain was maintained in all cases. Five grew parallel to their presenting weight centile. Only patient 6 was able to regain his original birth centile.

Five patients required home oxygen. Patients 7 and 9 have been successfully weaned into air. Patients 10 and 11 have been weaned to flow rates between 1 and 0.5 litres per minute while patient 5 needs nocturnal oxygen only.
All 11 patients are alive at a median age of 6 years since the diagnosis was made (range: 1 month to 10 years). Two patients are without symptoms. A further six infants have experienced dyspnoea with moderate activity. The remaining three affected children still require oxygen.

\section{Discussion}

This case series describes the clinical course of 11 children with interstitial pulmonary fibrosis presenting to one regional centre over an 11 year period. Despite previous reports of a poor prognosis in this age group, ${ }^{2-49}$ all our patients are alive at a median age of 6 years. This striking difference in prognosis in this series could be a reflection of the heterogeneous nature of the condition, with some of our patients showing milder pathology with less intense inflammation and fibrosis. However, this series does include patients with severe disease and even these patients are alive. In all except one patient immunosuppressive treatment has been limited to oral steroids with the addition of nutrional support and oxygenation. This may indicate that a more conservative approach avoiding more aggressive immunosuppressive therapy might have an advantage. Epidemiological research on the prevalence of interstitial disease in adults from the United States suggests that the condition is more common in the general population ${ }^{10}$ than previous estimates based on hospital records would suggest. ${ }^{11}$ There is evidence for great variability, both in the natural history of the disease and in its response to treatment. ${ }^{9}$ Some affected children have experienced spontaneous resolution without treatment, ${ }^{8}$ while others progress to death despite maximal therapy. ${ }^{2}$ Further research on the prevalence of idiopathic pulmonary fibrosis in the general paediatric population is needed in order that the aetiology and natural history may be better understood.

All of our patients experienced symptoms at a very early age. Half had symptoms at birth. This young age of presentation has been described in previous series. ${ }^{2412}$ Fan et al, in their series of 48 patients, noted that most patients had symptoms under 1 year of age. ${ }^{4}$ Osika et al reported that nine out of ten patients had symptoms below 2 months of age. ${ }^{2}$ Two of our patients were ventilated for short periods at low mean airway pressures. Neither had any histological changes associated with ventilation induced barotrauma or bronchopulmonary dysplasia. Four of our patients were born prematurely at 28, 33, 34, and 34 weeks respectively. None had a clinical presentation which was compatible with respiratory distress syndrome of the newborn. Three of these premature children had the first symptoms of interstitial lung disease after the neonatal period between 3 weeks and 2.5 months of age. The early appearance of symptoms in all of the infants in our series suggests that an in utero aetiology should be considered in infants with idiopathic pulmonary fibrosis. In contrast to 
previous reports, ${ }^{29}$ we did not find that a young age of presentation resulted in a worse prognosis.

The presenting symptoms of dyspnoea and cough were typical of previous series of interstitial lung disease. ${ }^{13}$ The importance of early diagnosis and treatment has been emphasised in previous studies. ${ }^{23}$ In this series we could find no difference in outcome between children who were diagnosed and treated early and those where diagnosis and treatment was delayed. Failure to thrive was a common finding at presentation and occurred despite a normal birth weight in most cases. Weight gain can be achieved if high energy supplements are provided.

In common with many previous reports we could find no relation between the severity of presenting symptoms, the findings on investigation, and the eventual outcome. ${ }^{3413}$ All patients had evidence of fibrosis on chest radiographs and CT scan. This fibrosis was diffuse in all cases. Patient 8 appeared to develop fibrosis over two years. In retrospect, he may have been diagnosed earlier had a lung biopsy been performed sooner. While the clinical presentation and radiological findings in our patient group were similar to those found in previous case series, ${ }^{2-49}$ the histology described in this report is by contrast less severe. There were no cases of LIP in this series. This may be because of the low incidence of paediatric human immunodeficiency virus infection in Merseyside. We saw histological evidence of severe fibrosis in only two patients while five infants showed moderate fibrosis. Cellular interstitial inflammatory infiltrate was either mild or moderate in all of the infants. By contrast, Osika and colleagues ${ }^{2}$ reported "intense to moderate fibrosis" in all cases and intense to moderate cellular infiltrate in six of the 10 infants in their series. In adults a good response to steroids and therefore a better prognosis has been observed in patients with a considerable cellular reaction ${ }^{14-16}$ and less fibrosis. ${ }^{17}$ Other investigators working with adult patients have found that neither degree of fibrosis nor cellular infiltrate relates to subsequent response to therapy and survival. ${ }^{18}$

In common with the findings of other paediatric case series, ${ }^{2} 7$ the severity of histological change in individual infants in this report did not relate to their response to steroids or their eventual outcome. Although one specimen obtained by percutaneous lung biopsy proved to be inappropriate for histological analysis, we believe that the percutaneous method is both safe and reliable. Percutaneous lung biopsy allows careful selection of the site of maximal lung abnormality seen on $\mathrm{CT}^{5}$ and has few side effects compared to open lung biopsy. ${ }^{19}$ Six of our patient group showed a favourable response to corticosteroids. The lack of response of patients to oral corticosteroids has been well documented. $^{24920}$ Steroid unresponsive disease may be caused by the presence of established and advanced pulmonary fibrosis prior to starting treatment. ${ }^{21}$ Alternatively, therapy with steroids may fail as steroids have been shown to have little effect on the cytokines known to promote fibroblast proliferation..$^{22}{ }^{23} \mathrm{~A}$ number of studies suggest that response to steroids is the most important factor in determining a good prognosis. ${ }^{9}{ }^{17} \mathrm{We}$ could find no differences in prognosis between those that received more than three months of oral steroids and those that did not. Success has also been described with the use of pulsed methylprednisolone. ${ }^{21324}$ A multicentre, randomised, double blind trial comparing oral prednisolone to both a placebo control and pulsed methylprednisolone is needed. Investigations to find an underlying cause of the interstitial disease proved unhelpful and the interstitial lung fibrosis described here is thought to be idiopathic in origin. Previous reports suggest that individual susceptibility is important ${ }^{25}$ and a familial form of the condition has been reported. ${ }^{26}$ We found no evidence of familial disease in our patients.

All patients who were assessed with respiratory function testing showed a restrictive pulmonary defect. As was previously reported, ${ }^{3}$ we did observe a mild increase in forced vital capacity in four of the five patients who had a prolonged steroid treatment course. We did not observe deterioration in lung function in those children whose steroids had been stopped. We found transient pulmonary hypertension in only one patient. This is a well recognised complication of idiopathic pulmonary fibrosis. ${ }^{4}$

Idiopathic pulmonary fibrosis appears to have a diverse natural history with a variable prognosis in early infancy, and the prognosis in some patients managed with only oral steroids and hydroxychloroquine can be good. Further research into the prevalence, aetiology, and pathology of this rare condition is required to enable treatments of proven efficacy to be developed.

1 Bokulic R, Hilman B. Interstitial lung disease in children. Pediatr Clin North Am 1994;41:543-67.

2 Osika E, Muller M-H, Boccon-Gibod L, Clement A Idiopathic pulmonary fibrosis in infants. Pediatr Pulmonol 1997;23:49-54

3 Steinkamp G, Muller K, Der Hardt H. Fibrosing alveolitis in children. Acta Paediatr Scand 1990;79:823-31.

4 Fan L, Mullen A, Brugman S, Inscore S, Parks D, White C. Clinical spectrum of chronic interstitial lung disease in children. $\mathcal{F}$ Pediatr 1992;121:867-72.

5 Smyth R, Carty H, Thomas H, van Velzen D, Heaf D. Diagnosis of interstitial lung disease by a percutaneous lung biopsy sample. Arch Dis Child 1994;70:143-4.

6 Chadelet K, Baculard A, Grimfeld A, Tournier G, Boule M, Boccon-Gibod L, Clement A. Pulmonary sarcoidosis in children: serial evaluation of bronchoalveolar lavage cells during corticosteroid therapy. Pediatr Pulmonol 1993;16: $41-7$.

7 Rudd R, Haslam P, Turner-Warwick M. Cryptogenic fibrosing alveolitis: relationship of pulmonary physiology and BAL to response to therapy and prognosis. Am Rev Respir BAL to response to

8 Polger G, Promadhat V. Pulmonary function testing in children: techniques and standards. Philadelphia: WB Saunders and Company, 1971.

9 Sharief N, Crawford O, Dinwiddie R. Fibrosing alveolitis and desquamative interstitial pneumonitis. Pediatr Pulmonol 1994;17:359-65.

10 Coultas DB, Zumwalt RE, Black WC, Sobomya R. The epidemiology of interstitial lung diseases. Am f Respir Crit Care Med 1994;150:967-72.

11 Scott J, Johnston I, Britton J. What causes cryptogenic fibrosing alveolitis? A case-control study of environmental exposure to dust. BMF 1990;301:1015-17.

12 Stillwell P, Norris D, O'Connel E, Rosenow E, Weiland L, Harrison E. Desquamative interstitial pneumonitis in children. Chest 1980;77:165-71.

13 Fan L, Langston C. Chronic interstitial lung disease in children. Pediatr Pulmonol 1993;16:184-96. 
14 Liebow A, Steer A, Billingsley J. Desquamative interstitial pneumonia. Am f Med 1965;39:369-404.

15 Carrington C, Gaensler E, Coutu R, Fitzerald M, Gupta R. Natural history and treatment course of usual and desquamative interstitial pneumonia. N Engl f Med 1978;298: $801-9$.

16 Turner-Warwick M, Burrows B, Johnson A. Cryptogenic fibrosing alveolitis: response to corticosteroid treatment and its effect on survival. Thorax 1980;35:593-9.

17 Winterbauer RH, Hammer SP, Hallman KO, et al. Diffuse interstitial pneumonitis: clinicopathological correlations in 20 patients treated with prednisolone/azathioprine. $A m \mathcal{F}$ Med 1978;65:661-72.

18 DeRemee RA, Harrison EG, Anderson HA. The concept of classic interstitial pneumonitis-fibrosis (CIP-F) as a clinicopathologic syndrome. Chest 1972;61:213-20.

19 Venn G. Open lung biopsy. Br f Hosp Med 1988;39:272-6.

20 Barnes S, Roberton N. Desquamative fibrosing alveolitis unresponsive to steroid or cytotoxic therapy. Arch Dis Child 1975;50:324-7.
21 Egan J, Woodcock A. Does the treatment of cryptogenic fibrosing alveolitis influence prognosis? Respir Med 1996; 90:127-30

22 Kelly J. Cytokines of the lung. Am Rev Respir Dis 1990;141 765-88.

23 Lacronique J, Rennard S, Bitterman P, Ozaki T, Crystal R. Alveolar macrophages in idiopathic pulmonary fibrosis have glucocorticoid receptors, but glucocorticoid therapy does not suppress alveolar macrophage release of fibronectin and alveolar macrophage derived growth factor. $A m$ Rev Respir Dis 1984;130:450-6.

24 Kerem E, Bentur L, England S, Resisman J, O'Brodovich K, Bryan A, Levison H. Sequential pulmonary function measurements during treatment of infantile chronic interstitial urements during treatment of infantile

25 Chan-Yeung M, Muller N. Cryptogenic fibrosing alveolitis. Lancet 1997;350:651-6.

26 Bitterman PB, Rennard SJ, Keogh BA, Wewers MD, Adelberg S, Crystal RG. Familial idiopathic pulmonary fibrosis: evidence of lung inflammation in unaffected family members. N Engl f Med 1986;314:1343-7.

\section{Rapid responses}

Letters on the following papers have been published recently as rapid responses on the $A D C$ website. To read these letters visit www.archdischild.com and click on "Read rapid responses":

Lung deposition of aerosol: a comparison of different spacers. HJ Zar, EG Weinberg, H J Binns, et al. Arch Dis Child 2000;82:495-8.

Paracetamol overdosage. J Whittle, B McGucken. Arch Dis Child 2000;82:428.

Deliberate sulphonylurea poisoning mimicking hyperinsulinaemia of infancy. L Owen, M Ellis, J Shield. Arch Dis Child 2000;82:392-3.

Risk assessment of renal cortical scarring with urinary tract infection by clinical features and ultrasonography. MT Christian, JH McColl, JR MacKenzie, et al. Arch Dis Child 2000;82:376-80.

Anthropometric indices of failure to thrive. P Raynor, MCJ Rudolf. Arch Dis Child 2000;82:364-5.

Sputum induction for the diagnosis of pulmonary tuberculosis in infants and young children in an urban setting in South Africa. H J Zar, E Tannenbaum, P Apolles, et al. Arch Dis Child 2000;82:305-8.

Dipstick examination for urinary tract infections. S Thayyil-Sudhan, S Gupta. Arch Dis Child 2000;82:266.

Effect of prone sleeping on circulatory control in infants. A Chong, N Murphy, T Matthews. Arch Dis Child 2000;82:253-6.

Fits, pyridoxine, and hyperprolinaemia type II. V Walker, GA Mills, SA Peters, et al. Arch Dis Child 2000;82:236-7.

Proteus syndrome and immunodeficiency. D Hodge, SA Misbah, RF Mueller, et al. Arch Dis Child 2000;82:234-5.

Is routine growth monitoring effective? A systematic review of trials. $\mathrm{P}$ Garner, $\mathrm{R}$ Panpanich, $\mathrm{S}$ Logan, et al. Arch Dis Child 2000;82:197-201.

Is the Children Act failing severely abused and neglected children? N Speight, J Wynne. Arch Dis Child 2000;82:192-6.

Guidelines for the ethical conduct of medical research involving children. Royal College of Paediatrics and Child Health: Ethics Advisory Committee and Professor Sir David Hull. Arch Dis Child 2000;82:177-82.

Sedation of children for magnetic resonance imaging. GR Lawson, RJ Bray. Arch Dis Child 2000;82:150-3.

MMR vaccine and allergy. R Lakshman, A Finn. Arch Dis Child 2000;82:93-5.

School based screening for hypothyroidism in Down's syndrome by dried blood spot TSH measurement. SE Noble, K Leyland, CA Findlay, et al. Arch Dis Child 2000;82:27-31.

Dietary products used in infants for treatment and prevention of food allergy. Joint statement of the European Society for Paediatric Allergology and Clinical Immunology (ESPACI) Committee on Hypoallergenic Formulas and the European Society for Paediatric Gastroenterology, Hepatology and Nutrition (ESPGHAN) Committee on Nutrition. A Host, B Koletzko, S Dreborg, et al. Arch Dis Child 1999;81:80-4.

If you would like to post an electronic response to these or any other articles published in the journal, please go to the website, access the article in which you are interested, and click on "eLetters: Submit a reponse to this article" in the box in the top right hand corner. 